\title{
Review of: "Evaluation of the genotoxicity in fish erythrocytes to diagnose the water quality of two Amazonian estuaries using the micronucleus test and comet assay"
}

\author{
Madhu Sharma
}

Potential competing interests: The author(s) declared that no potential competing interests exist.

1. History of both genotoxic parameters is given in introduction as these parameters are very old and known so need not to include.

2. It is mentioned that bauxite smelting operations take place in that area. Any reference related to such activities may be included.

3. As the study is the comparison between an anthropogenic site and control site. Any studies which show the concentration of different pollutants on anthropogenic site.

4. More water parameters need to do to see the overall quality of water at both the site.

5. It is mentioned that different size fish weirs were used to catch the fish of specific size. But later in the text, it is not mentioned that which particular group or sex was selected for the sampling.

6. Visual classification was used to study the DNA damage by the comet assay. Any parameter of comet assay can be used to have better picture.

7. It is also no clear in the text that the blood smear prepared for micronucleus assay was at the site of collection or later in the laboratory.

8. Photographs of comet assay and micronucleus assay may be included.

9. Number of references are very high that may be reduced as per the research paper

10. Discussion has to be written properly e,g parameters were discussed at two place in discussion why? 